\title{
CONSTITUTIONALITY OF COMPULSORY STATIS- TICAL REPORTS OF THE FEDERAL TRADE COMMISSION
}

\section{Leighton P. Stradley}

How far can the Federal Trade Commission, a purely administrative body, compel a private corporation to render reports and submit statistics dealing with matters which are usually considered trade secrets or matters of purely private concern? This is a question of deep significance today, especially in view of its relation to the broader general subject of government by administrative bodies, a subject which seems bound to become more prominent in consequence of the increasing tendency of Congress to delegate its powers to commissions of various kinds.

Professor William Z. Ripley, of Harvard, in his article ${ }^{1}$ which states the case for the right of shareholders to receive more adequate information concerning the financial affairs of their corporation, advocates and defends the exercising of almost unlimited power by the Commission in this respect. But the attitude of the federal courts toward this question, although by no means settled, has reflected a tendency to interpret somewhat restrictively the powers of the Commission under the Federal Trade Commission Act. ${ }^{2}$ The Supreme Court in the Claire Furnace Company case, ${ }^{3}$ the most recent involving the point, unfortunately avoided the real question, leaving the issue still undetermined.

Dr. Ripley points out that it appears to be the general practice of corporations to issue balance sheets and income statements that are not fully informative to their stockholders or to the investing public. He suggests as a corrective and controlling remedy that the Federal Trade Commission exercise the authority

\footnotetext{
- 'The Shareholder's Right to Adequate Information, Attantic Montmly (September, 1926) 380. A phase of the same subject was dealt with in (I927) 75 U. of PA. L. REV. 350, Note.

${ }^{2} 38$ Stat. 717. (I9I4), U. S. Comp. Stat. (Igi8) § 8836a et seq.

${ }^{2}$ F. T. C. et al v. Claire Furnace Co. et al., 47 Sup. Ct. 553 (1927). See also the decision in the lower court, infra note 15 .
} 
given it under Section 6 of the Federal Trade Commission Act, which empowers it (a) to gather and compile information concerning the organization, business and management of corporations engaged in commerce, and (b) to require such corporations to file with the Commission certain specific reports in writing and under oath. He states that such action by the Commission would not require further legislation, and could be established as an administrative policy if the President of the United States should take the initiative.

It would seem that this eminent economic authority, although graphically setting forth known practices of withholding corporate information, has suggested a remedy that is not fully available, according to decisions under the Federal Trade Commission $A c t$, to which he refers. The $A c t$, Section 6, reads in part as follows:

"That the Commission shall have power . . .

"a. To gather and compile information concerning and to investigate from time to time the organization, business conduct, practices, and management of any corporation engaged in commerce, excepting banks and common carriers subject to the Act to regulate commerce, and its relations to other corporations and to individuals, associations, and partnerships."

"b. To require, by general or special orders, corporations engaged in commerce, excepting banks, and common carriers subject to the $A c t$ to regulate commerce, or any class of them, or any of them respectively, to file with the Commission in such form as the Commission may prescribe annual or special, or both annual and special, reports or answers in writing to specific questions, furnishing to the Commission such information as it may require as to the organization, business conduct, practices, management and relation to other corporations, partnerships and individuals of the respective corporations filing such reports or answers in writing. Such reports and answers shall be made under oath, or otherwise, as the Commission may prescribe, and shall be filed with the Commission within such reasonable time as the Commission may prescribe, unless additional time be granted in any case by the Commission." 
"d. Upon the direction of the President or either House of Congress to investigate and report the facts relating to any alleged violations of the anti-trust acts by any corporation."

-Decisions which interpret Section 6 of the Federal Trade Commission Act indicate that the powers granted may be used only where (I) inter-state commerce is involved, or (2) where Congress exercises visitorial powers over corporations as a legislative function, giving the Commission the right to examine into corporate affairs through some agency or instrumentality. Recognizing this, Dr. Ripley emphasizes, in his article, in support of his suggestion, the plenary authority of the United States. It may, however, be properly assumed, in view of the present law and its decisions, that the "plenary authority" is based solely on such federal jurisdiction as may follow the commerce clause or the exercise of visitorial powers.

It will be noted, on examination of the cases hereinafter cited, that while, in almost every case, interstate commerce is involved, the courts have taken the position that reports and other information cannot be required indiscriminately of corporations by the Federal Trade Commission because the reports must, of necessity, involve not only interstate, but intrastate commerce as well. As to intrastate affairs, Congress has no authority to impose such conditions. It may be safely predicted that the Federal Trade Commission cannot exercise the sweeping powers as to reports which Dr. Ripley proposes under the commerce clause, as his report plan is not based on regulation of commerce in the true meaning of that term, but more strictly is a financial. or investment measure over which Congress has no jurisdiction under the Constitution, the sole source of Con- . gressional authority.

It is also apparent, from the examination of the cases, that Congress cannot, in this manner exercise visitorial powers over private corporations. Admittedly this may be a proper legislative function, especially under state laws. It has been held, however, as a matter of federal jurisdiction, that the power can be exercised only by the federal judiciary or by direct committees 
of Congress, and even in such cases, the visitorial powers of Congress are limited to subject matters over which Congress has control and which, under the Constitution, it has power to regulate. Inasmuch as the Commission is quasi-judicial only and is not a Congressional committee, the authority to exercise this power in cases where no violation of the law is alleged, rests in the courts or in such committees, and delegation of such power by the legislative branch of the Government to a mere administrative body such as the Federal Trade Commission is of most doubtful legality.

Moreover, there is ample authority that even though the commerce clause or the visitorial power might be properly invoked, an effort by the Federal Trade Commission to delve into the affairs of private corporations, whether under report requirements or by sending agents to examine books, records and papers for publicity purposes, is unconstitutional as an unreasonable search and seizure. Corporations may claim protection against this under the Constitution of the United States.

Dr. Ripley acknowledges that decisions of Federal Courts have held that the Commission has no authority to enforce Section 6 of the Act in cases of this kind. He refers to an argument then before the United States Supreme Court (evidently the Claire Furnace case mentioned above) ${ }^{4}$ and thinks chances of affirmation to require federal reports are good, in view of trust and railroad litigation before that Court heretofore having resulted in favor of the plenary authority of the United States.

The first case before the courts was that of the United States v. Basic Products Co. ${ }^{5}$ In this case Section 6 was invoked by the Federal Trade Commission, through the Attorney-General of the United States. This official filed a petition for a writ of mandamus to compel the Basic Products Company to submit its books for inspection so that the cost of its product could be determined to settle a controversy which that Company had with the Navy Department over a war contract. The mandamus was denied the Commission. The Court held (after concluding that interstate

'Ibid.

260 Fed. 472 (W. D. Pa. 1919). 
commerce was not directly involved) that the argument of counsel for defendant was sound in contending that Section 6 was unconstitutional "insofar as it authorizes investigations and compulsory disclosures of matters which are beyond the commerce power of Congress" and also "insofar as it attempts to authorize a search or seizure by an administrative agency of the Government without charge or suspicion of worongdoing."

In Maynard Coal Company v. Federal Trade Commission, ${ }^{\circ}$ argued in the Supreme Court of the District of Columbia, the coal company applied for an injunction to restrain the Commission from taking steps to collect a penalty for failure to make reports called for by the Commission. The Commission demanded information as to monthly costs of production and other data from a large number of coal mining companies for each month of the year 1920 , and until further notice. The Commission based its authority on Section 6 of the Federal Trade Commission Act, alleging that Congress had full authority in the premises under the commerce clause of the Constitution. In that case, it was admitted that the Coal Company was not charged with unfair methods of competition, nor was it charged with any violation of the Federal Trade Commission Act or the antitrust acts, the Sherman $A c t^{7}$ of 1890 and its supplement, the Clayton Act ${ }^{8}$ of 1914 .

After reveiwing the facts and authorities, showing that intrastate as well as interstate commerce was involved, the Court said : 9

"In order for the Federal Trade Commission to have the power to require the plaintiff to make reports as to the mining of coal and as to its intrastate shipments, it must appear that this information is necessary to or connected with some subject over which the general government has power. There is no claim made that there is any proceeding pending, involving the Anti-trust Act, or unfair methods of competition, or under the Clayton Act, but in its order

- 48 Wash. L. Reporter 278 (April 30, 1920).

' 26 Stat. 209 ( (1890), U. S. Comp. Stat. (IgI8) $\$ 8820$ et seq.

s 38 Stat. 730 (IgI4), U. S. CoMp. Stat. (IgI8) \$ 8835 a et seq.

- Supra note 6 at 280. 
defendant demands reports in all the business of the plaintiff.

"The defendant relies upon the visitorial powers of Congress over corporations. In this connection, it must be borne in mind that the power of Congress over an ininstrumentality of commerce, such as a common carrier, is far different from its powers over an ordinary business corporation.

"Apart from the fact that plaintiff is a corporation, it is clear the Congress could not compel the production of the private books and papers of a citizen, except in the progress of judicial proceedings.

"But the Commission has undertaken to construe the $A c t$ otherwise and to take steps under its construction to the $A c t$ to require information and reports not relating to interstate commerce, but relating chiefly or wholly to production, and under its order the information which it has the power to demand cannot be separated from that over which it has no control."

In other decisions recently handed down, and especially in the Baltimore Grain Company case ${ }^{10}$ and the Tobacco Companies cases, ${ }^{11}$ where arguments in favor of compulsory reports were urged, lower courts decided adversely. The Commission sought a mandamus to permit agents of the Commission to examine books, records, documents, etc., of these companies. The Commission acted on its own motion, under Section 6, and also pursuant to a Senate resolution, directing the Commission to investigate the margins between farm and export prices... the profits or losses of the principal exporting firms and other data. The Court said:

"The precise question here to be decided is whether the statute confers upon the Commission the right to inspect and copy the papers of any private corporation engaged in interstate or foreign commerce, whenever, in the judgment of the Commission, such inspection may furnish informa-

${ }^{10}$ Three cases were decided in one opinion and are reported in Federal Trade Commission v. The Baltimore Grain Company; H. C. Jones Co., Inc., and Hammond Snyder Co., Inc., 284 Fed. 886 (D. C. Md. Ig22); aff'd 267 U. S. 586 (1924).

III Infra note 13. 
tion of value to an inquiry it is making as to some economic or commercial problem, and when it has no reason to believe that any violation of law has been committed."

The Court held that the threatened search and seizure by the agents of the Commission was unreasonable and prevented it by denying the petition for the mandamus. On appeal to the Supreme Court of the United. States, this decision was affirmed in a per curiam opinion. ${ }^{12}$

Other recent and conclusive cases on the subject are Federal Trade Commission v. P. Lorillard Company and American Tobacco Co., ${ }^{13}$ two cases decided in one written opinion, by the United States District Court for the Southern District of New York. The Commission in pursuance of a Senate resolution, demanded an examination of the books, records and papers. of these companies. The Court held that while the President or either House of Congress can call upon the Federal Trade Commission, under Section 6, to make investigations, it nevertheless can do so only by alleged violations of the anti-trust acts. The Court in construing Section 6 , inter alia, said: $:^{14}$

"Reading Secs. 5, 6, and 9, I do not think that Congress intended, at the time of the enactment of this law, to go beyond the well-recognized principles of limitations with reference to searches and seizures guarded against by the Fourth Amendment of the Constitution. 'It is better to deduce the intention that information should only be extracted by the procedure long established in the courts in conformity. with the Constitutional guarantee against unlawful and unreasonable searches and seizures and the right of people to be secure in their papers and effects therefrom."

On appeal to the United States Supreme Court, the decision of the lower court was affirmed. Mr. Justice Holmes delivered the opinion of the Court, and said inter alia: ${ }^{15}$

\footnotetext{
${ }^{23} 267$ U. S. 586 (1924).

${ }^{22} 283$ Fed. 999 (S. D. N. Y. I922) ; aff'd 264 U. S. 298 (1924).

"Ibid. at I005.

${ }^{15} 264$ U. S. 298, 305 (I924).
} 
"The mere facts of carrying on a commerce not confined within state lines and of being organized as a corporation do not make men's affairs public, as those of a railroad company now may be. . . . Anyone who respects the spirit as well as the letter of the Fourth Amendment would be loath to believe that Congress intended to authorize one of its subordinate agencies to sweep all our traditions into the fire, . . . and to direct fishing expeditions into private papers on the possibility that they may disclose evidence of crime. We do not discuss the question whether it could do so if it tried, as nothing short of the most explicit language would induce us to attribute to Congress that intent. The interruption of business, the possible revelation of trade secrets, and the expense that compliance with the Commission's wholesale demand would cause are the least considerations. It is contrary to the first principles of justice to allow a search through all the respondents' records, relevant or irrelevant, in the hope that something will turn up."

The federal courts intimated, and it undoubtedly is so, that states granting charters to corporations would have power to exact reports as a reserved power in granting such charters. Dr. Ripley wisely concludes, however, that attempted state regulation of the matter would be futile as a practical remedy, because of diversified conditions and because of the inability of state laws to operate extraterritorially.

The Supreme Court of the District of Columbia also entered a decree enjoining the Commission from collecting penalties in a similar situation in Claire Furnace Company et al. v. Federal Trade Commission. ${ }^{16}$ Here the Commission demanded not only reports and statistics but also income statements and balance sheets, in pursuance of a request of a congressional committee which was investigating prevailing high prices in certain basic commodities. The case was appealed to the Supreme Court of the United States, and was argued twice before that Court. The argument of the Government rested largely on the ground that the demand of the Commission was not an unreasonable invasion of privacy, and that the information sought was an appropriate

${ }^{28} 28$ Fed. 936 (Ct. of App. D. C. 1923). 
means of regulating interstate commerce. The defense relied mainly on the fact that the demand for the reports was an unreasonable invasion of privacy and therefore contrary to the Fourth Amendment of the Constitution of the United States. It was also argued that the information sought was not an appropriate means of regulating interstate commerce, inasmuch as the intrastate activities of the companies called on for reports were so interwoven with their interstate business that it was impossible to separate them; and even if separated, such separation would result in inaccurate and valueless information.

In addition to this, the defendants objected that the information could not be called for except for use in pending legal proceedings involving specific charges of unfair competition or violation of the anti-trust acts, or for immediate use in connection with some concrete proposal for legislation pending in Congress.

Further, the Court was reminded of the fact that the reports called for would disclose costs and profits which, in general practice, are jealously guarded secrets of every manufacturer, because a disclosure of these to competitors is, and always has been, detrimental to management of manufacturing companies in price quoting. Losses due to this, it would seem, might outweigh advantages to the very stockholders whom Dr. Ripley, by his publicity plan, would hope to benefit.

Unfortunately, the Supreme Court did not meet or decide the issue in its decision, and dismissed the bill for want of equity. The Court found that the bill in equity, to enjoin the Commission from attempting to enforce its orders, was improper procedure, in view of the express terms of the Federal Trade Commission Act, which provides (Section 10) that failure to file reports demanded by the Commission carries a money forfeit, payable by civil suit brought in the name of the Government, through the Attorney General of the United States.

The dissenting opinion of Mr. Justice McReynolds is most significant when he said that "the Commission went beyond any power granted by Congress" in demanding the reports. It is not unreasonable to assume that that might well reflect the opinion of the Court if it had then decided these cases on their merits. 
In conclusion, it may be said that practices complained of present an evil for which there may be no remedy, at least in so far as federal aid or regulation is concerned, and in particular any attempted effort to effect relief through the medium of the Federal Trade Commission. It would involve a great stretch of imagination to take any decided case as authority for demanding the reports called for by Dr. Ripley through the Federal Trade Commission, where the purpose is not, in any way, connected with the regulation of interstate commerce, but is to supply financial data to stockholders and investors. This is as far removed from the category of the regulation of interstate commerce as it is possible to conceive. The Trade Commission itself has recognized this in its recent request to the Attorney General to discontinue action in the Republic Iron and Steel, Bethlehem Steel, and in other cases where the Trade Commission was seeking similar reports.

A reference to Judge Sawyer's opinion In re Pacific Railway Commission, ${ }^{17}$ seems peculiarly applicable to this proposal, in which the Court said:

"A general, roving, offensive, inquisitorial, compul-. sory investigation, conducted by a commission without any allegations, upon no fixed principles, and governed by no rules of law, or of evidence, and no restrictions except its own will, or caprice, is unknown to our constitution and laws; and such an inquisition would be destructive of the rights of the citizen, and an intolerable tyranny. Let the power once be established, and there is no knowing where the practice under it would end."

${ }^{17} 32$ Fed. 24I, 263 (N. D. Calif. I887). 